\title{
Urgensi Pelatihan KTI untuk Meningkatkan Kompetensi Widyaiswara dalam Penulisan Karya Ilmiah
}

\author{
Wirda \\ Widyaiswara Ahli Madya Bapelkes Provinsi Jambi, \\ Jl. Lintas Jambi-Muara Jambi, Pijoan Kab .Muara Jambi \\ Correspondence email: wirdaedi9@gmail.com
}

\begin{abstract}
The objectives of this research are as follows: 1) The skills of the Jambi Bapelkes widyaiswara in making scientific papers, 2) The constraints of the Jambi Bapelkes Widyaiswara in making scientific papers, 3) The efforts made by the Jambi Bapelkes widyaiswara in improving the ability to make scientific papers. This study uses a qualitative approach with a phenomenological design. Methods of data collection using interviews, observation, and documentation study. The data validity technique used source and technique triangulation. While the data analysis technique uses an interactive model with the process of data collection, data reduction, data presentation and conclusions. The results of this study can be seen as follows: First, the skills of lecturers in writing KTI are sufficient, although there are several aspects that must be improved, Second, some of Widyaiswari's obstacles in compiling KTI are related to opportunities, book research, limited supporting facilities and lack of motivation. , ketiga, Some of the efforts made to improve skills in preparing KTI are through: training of trainers, training, participating in webinars, work shops, a lot of literacy on the results of previous research, and following tutorial activities on YouTube.
\end{abstract}

\section{Keywords: Competence, Scientific Writing, Education and Training}

\section{Pendahuluan}

Salah satu faktor yang berpengaruh terhadap berlangsungnya kegiatan pelatihan dan Pendidikan yaitu widyaiswara yang merupakan salah satu jabatan fungsional yang cukup menentukan dalam berjalannya roda pemerintahan, terutama dalam mewujudkan pemerintahan yang baik (good governance) dan membentuk lembaga pemerintah yang bersih (clean government). Widyaiswaralah salah satu unsur yang membangun karakter dan kompetensi Aparatur Sipil Negara (ASN) melalui kegiatan pendidikan, pengajaran dan pelatihan. Maka sejalan dengan perkembangan ilmu pengetahuan dan teknologi, kapasitas ASN perlu terus dikembangkan agar dapat menjalankan tugas-tugas pemerintahan, pembangunan dan pelayanan masyarakat yang berkualitas. Keberhasilan penyelenggaraan pendidikan dan pelatihan ditentukan oleh empat pilar kediklatan, yaitu widyaiswara, program diklat, penyelenggara diklat yang melayani para peserta, dan tersedianya sarana prasarana. Keempat pilar ini merupakan satu kesatuan yang tidak dapat dipisahkan. Salah satu bentuk keberhasilan pendidikan dari aspek kewidyaiswaraan adalah mereka memiliki kompetensi dalam menulis dan menyusun karya tulis ilmiahnya sebagai unsur pokok untuk naik ke jabatan yang lebih tinggi, karena salah satu unsur yang dapat dikatakan sulit untuk diperoleh oleh widyaiswara saat ini di unsur pengembangan profesinya yaitu karya tulis ilimiah. Menurut (Zainuddin, 2014) bahwa seorang yang profesional dalam menjalankan tugasnya, ia bertindak atas dasar kaidah-kaidah ilmiah untuk meningkatkan mutu pendidikan.

Karya tulis ilmiah adalah salah satu indikator penguasaan kompetensi profesional, termasuk widyaiswara, sekaligus menjadi media atau sarana komunikasi dalam menuangkan gagasan dan pengetahuannya dalam rangka mengembangkan bahan ajar dan menjamin efektifitas proses pembelajaran. Mengingat begitu pentingnya karya ilmiah untuk pengembangan profesionalisme widyaiswara, maka bukan hanya kuantitas yang harus diperhatikan, namun kualitas juga menjadi patokan utama dalam rangka pemenuhan karya tulis tersebut. Untuk terwujudnya widyaiswara yang mahir dalam menulis dan mempublikasikan karya ilmiahnya dibutuhkan pengetahuan dan kompetensi yang mempuni. Dalam hal ini, (Megawati, 2012) menyebutkan bahwa Kompetensi mengacu pada kemampuan melaksanakan sesuatu yang diperoleh dari pendidikan, yang memerlukan pengetahuan.

Berdasarkan kenyataan di lapangan menunjukkan bahwa tidak semua widyaiswara memiliki kompetensi yang mampuni dalam bidang publikasi ilmiah sebagai suatu kewajiban yang harus dilakukan oleh mereka terutama saat pengajuan dupak, hal ini masih terkendala pada unsur karya tulis ilmiah yang tidak mencukupinya. Untuk lebih jelasnya mengenai jumlah publikasi rata-rata widyaiswara atau jumlah usulan dupak yang tidak memenuhi dapat diperhatikan pada tabel berikut: 
Tabel 1.

Klasifikasi Widyaiswara yang Belum Memenuhi Unsur Publikasi Ilmiah Masa Penilaian: 02 Januari Sampai dengan 30

Desember 2020

\begin{tabular}{l|l|l|r|r|r|r}
\hline No & \multicolumn{1}{|c|}{ Nama } & \multicolumn{1}{|c|}{ Nip dan jabatan } & Jumlah AK & Jumlah Ak yang harus dipenuhi & Kekurangan & \\
\hline 1 & Dr. Hj. Wirdam SKM, M.Kes & Pembina Tk.I IV/b & 661,120 & 700 & $-38,880$ & Belum memenuhi \\
\hline 2 & Dra. Helni, Apt, M Kes & Pembina Tk I IV/b & 755,070 & 700 & & $\begin{array}{l}\text { Sudah memenuhi tetapi blm bisa naik pangkat kejenjnag lbh tinggi } \\
\text { karena unsur pengembangan profesi masih kurang }\end{array}$ \\
\hline 3 & Ns. Hasbi, S.Kep, MKM & Penata III/c & 226,225 & 400 & $-173,775$ & Belum memenuhi \\
\hline 4 & dr Hasanah Suryani Utami & Penata TK I III/d & 325,060 & 400 & $-74,94$ & Belum memenuhi \\
\hline
\end{tabular}

Sumber: Olahan Data

Berdasarkan tabel 1 di atas menunjukkan bahwa, terdapat beberapa widyaiswara yang terhalang untuk menaiki Pangkat atau Jabatan yang lebih tinggi karena terkendala pada unsur publikasi ilmiah atau karya tulis ilmiahnya. Hal tersebut di atas sangatlah beralasan kalau seorang widyaiswara harus memiliki keterampilan menulis karya tulis ilmiah, namun secara faktual masih banyak widyaiswara yang masih kesulitan mengumpulkan angka kredit dari aspek pengembangan profesi dari menyusun karya tulis ilmiah. Memperhatikan begitu urgensinya kompetensi widyaiswara dalam bidang karya tulis ilmiah, maka sebagai salah satu upaya yang dapat dilakukan dalam dunia kediklatan adalah mengikuti kegiatan pelatihan karya tulis ilmiah atau Training of Trainer. Sehingga di dalam kegiatan pelatihan tersebut widyaiswara akan di latih untuk meningkatkan profesinya dalam hal menulis berbagai bentuk tulisan termasuk membuat buku, menulis artikel dan sebagainya. Adapun yang menjadi tujuan utama dari penulisan jurnal ini adalah Mengetahui Kompetensi Menulis Bagi Widyaiswara, Mengetahui kendala widyaiswara dalam kegiatan menulis dan Mengetahui upaya meningkatkan kompetensi menulis widyaiswara.

\section{Kompetensi Widyaiswara}

Pengertian widyaiswara sebagaimana dalam Kamus Besar Bahasa Indonesia adalah sebagai jabatan fungsional yang diberikan kepada pegawai negeri sipil dengan tugas mendidik, mengajar dan/atau melatih secara penuh pada unit pendidikan dan pelatihan dari instansi pemerintah. (Karyana, 2016) menjelaskan bahwa widyaiswara berasal dari bahasa sansekerta, yaitu dari kata Vidya yang berarti ilmu pengetahuan, kata Ish yang berarti memiliki, dan kata Vara berarti terpilih. Peraturan Menteri Pendayagunaan Aparatur Negara dan Reformasi Birokrasi Republik Indonesia nomor 22 Tahun 2014 mendefinisikan widyaiswara adalah PNS yang diangkat sebagai pejabat fungsionaldengan tugas, tanggung jawab, wewenang, dan hak untuk melakukan kegiatan Dikjartih PNS, Evaluasi dan Pengembangan Diklat pada Lembaga Diklat Pemerintah. Sehingga secara sederhana Widyaiswara dapat diartikan sebagai seorang yang memiliki ilmu pengetahuan dan terpilih yang memiliki tugas mengajar dan atau melatih PNS di lingkungan pemerintahan.

Peraturan Kepala Lembaga Administrasi Negara (LAN) Nomor 5 Tahun 2008 menjelaskan bahwa standar kompetensi widyaiswara adalah kemampuan minimal yang secara umum dimiliki oleh seorang widyaiswara dalam melaksanakan tugas, tanggungjawab dan wewenangnya untuk mendidik, mengajar, dan/atau melatih PNS yang terdiri atas kompetensi pengelolaan pembelajaran, kompetensi kepribadian, kompetensi sosial, dan kompetensi substantif. Peraturan Menteri Pendayagunaan Aparatur Negara dan Reformasi Birokrasi No.22 Tahun 2014 menegaskan bahwa seorang Widyaiswara harus memiliki kompetensi atau kemampuan pendidikan, pelaksanaan dikjartih PNS, evaluasi dan pengembangan diklat, dan pengembangan profesi sebagai unsur utama dan unsur penunjang. Kompetensi itu sendiri digambarkan sebagai kemampuan untuk melaksanakan satu tugas atau peran. Adapun indikator kompetensi adalah pengetahuan, ketrampilan-ketrampilan, sikap-sikap dan nilai-nilai pribadi, dan kemampuan untuk membangun pengetahuan dan keterampilan yang didasarkan pada pengalaman dan pembelajaran yang dilakukan. Kompetensi yang dimaksud disini adalah tentang kemampuan atau upaya yang dilakukan dari Widyaiswara itu sendiri dalam menjalakankan tugasnya sesuai dengan PERMENPAN No. 14 tahun 2009. Dalam redaksi lain, (Fakhrurriza dan nurdin 2019) menyatakan bahwa seorang pendidik profesional akan tercermin dalam penampilan pelaksanaan pengabdian tugas-tugas yang ditandai dengan keahlian baik dalam materi maupun metode. Keahlian yang dimilki oleh guru profesional adalah keahlian yang diperoleh malalui suatu proses pendidikan dan pelatihan yang diprogramkan secara khusus.

Dalam Peraturan Kepala Lembaga Administrasi Negara (Perka-LAN) Nomor 9 tahun 2008 tentang Pendoman Penyelenggaraan Diklat Kewidyaswaraan Berjenjang, dinyatakan bahwa setiap jenjang widyaiswara memiliki standar kompetensi dalam melaksanakan tugas, yaitu :

a) Widyaiswara Pertama, memiliki kompetensi dalam membuat rancang bangun kegiatan pembelajaran mulai dari penyusunan GBPP, SAP, bahan diklat sampai teknik evaluasi pembelajaran. Kemudian juga menguasai analisis kebutuhan diklat, mampu memberikan pelayanan prima dalam bidang pembelajaran sesuai dengan proses pembelajaran orang dewasa, serta mampu membuat karya tulis ilmiah dan menguasai teknik evaluasi diklat,

b) Widyaiswara Muda, memiliki kompetensi mampu dalam membuat rancang bangun kegiatan pembelajaran yang diterapkan secara konvensional maupun diklat jarak jauh sesuai dengan prinsip pembelajaran orang dewasa. 
Kemudian mampu mengobservasi proses pembelajaran, membuat karya tulis dan mengelola forum ilmiah, serta mampu membimbing praktek kerja lapangan dan penulisan kertas kerja,

c) Widyaiswara Madya, memiliki kompetensi dalam membuat rancang bangun kurikulum diklat sesuai dengan prinsip andragogi yang diterapkan secara konvensional maupun diklat jarak jauh. Kemudian juga mampu membuat karya tulis dan mengelola forum ilmiah, mampu menilai angka kredit jabatan fungsional widyaiswara, serta dapat membimbing praktek kerja lapangan dan penulisan kertas kerja,

d) Widyaiswara Utama, memiliki kompetensi dalam membuat rancang bangun kurikulum melalui analisis mikro kebutuhan diklat sesuai dengan filsafat belajar andragogi yang diterapkan secara konvensional maupun diklat secara jarak jauh. Kemudian dapat menerapkan teknik komunikasi interpersonal, merancang penelitian kualitatif, dan perkonsultasian penyelenggaraan diklat. Diharapkan dapat membimbing praktek kerja lapangan dalam segala jenis diklat serta menerapkan teknik observasi dan evaluasi portofolio diklat.

Semua tingkatan widyaiswara tersebut dibutuhkan kompetensi menulis, terutama dalam membuat karya tulis ilmiah. Bahkan untuk naik ke jenjang Widyaiswara Ahli Utama diharuskan melakukan penelitian dan membuat karya tulis ilmiah yang kemudian disampaikan dalam sebuah acara orasi ilmiah. Dalam Peraturan Kepala LAN-RI Nomor 3 tahun 2006 tentang Pedoman Pelaksanaan Orasi Ilmiah Widyaiswara, dinyatakan bahwa setiap widyaiswara diharuskan untuk melakukan orasi ilmiah sebagai persyaratan untuk naik jabatan ke Widyaiswara Ahli Utama.

Dalam Peraturan Kepala LAN-RI Nomor 9 tahun 2008 tentang Pedoman Penyusunan Karya Tulis Ilmiah dinyatakan bahwa karya tulis ilmiah juga merupakan indikator penguasaan kompetensi profesional widyaiswara dan sekaligus media atau sarana komunikasi bagi widyaiswara dalam menuangkan gagasan dan pengetahuannya dalam rangka mengembangkan bahan ajar dan menjamin efektifitas proses pembelajaran. Kemudian dapat memahami secara tepat jalan fikiran dan kandungan materi yang termuat dalam KTI widyaiswara yang bersangkutan. Kemampuan membuat karya tulis ilmiah adalah kompetensi yang harus dimiliki oleh setiap widyaiswara, mulai dari tingkat pertama hingga utama, karena semua tugas widyaiswara tersebut behubungan dengan tulis-menulis.

Kemudian dalam pasal 8 huruf d Peraturan Menteri Pemberdayaan Aparatur Negara dan Reformasi Birokrasi (PAN-RB) Nomor 22 tahun 2014 tentang Jabatan Fungsional Widyaiswara disebutkan bahwa salah satu unsur pengembangan widyaiswara adalah membuat karya tulis ilmiah dalam bidang keahliannya dalam lingkup kediklatan.

Pada pasal 8 huruf d Peraturan Menteri PAN Nomor 22 Tahun 2014 tentang Jabatan Fungsional Widyaiswara, dinyatakan sub unsur pengembangan profesi terdiri atas :

a) Pembuatan karya tulis / karya ilmiah dalam bidang spesialisasi keahliannya dan lingkup kediklatan,

b) Penemuan inovasi yang dipatenkan dan telah masuk daftar paten sesuai bidang spesialisasi keahliannya,

c) Penyusunan buku pedoman / ketentuan pelaksanaan / ketentuan teknis di bidang kediklatan,

d) Pelaksanaan orasi ilmiah sesuai spesialisasinya.

Kemudian pada huruf e pasal tersebut dinyatakan kegiatan penunjang Jabatan Fungsional Widyaiswara, meliputi: a) Peran serta dalam seminar/lokakarya/konferensi di bidang kediklatan, b) Keanggotaan dalam organisasi profesi, c) Pembimbingan kepada widyaiswara dibawah jenjang jabatannya, d) Penulisan artikel pada surat kabar, e) Penulisan artikel pada website, f) Perolehan gelar/ijazah kesarjanaan lainnya, dan g) Perolehan penghargaan/tanda jasa.

Pasal tersebut tersirat bahwa pekerjaan widyaiswara tidak bisa lepas dari kompetensi dan kemampuan membuat karya tulis ilmiah. Menulis adalah bagian penting bagi widyaiswara, disamping mendidik, mengajar, melatih, mengevaluasi dan pengembangan. Begitu juga dengan angka kredit yang diperoleh dari aktifitas menulis yang cukup besar dibandingkan kegiatan lainnya. Untuk lebih jelasnya terkait dengan jabatan fungsional widyaiswara dan angka krediknya dapat diperhatikan sesuai dengan Keputusan Permenpan Kepala Lembaga Administrasi Negara No. 26 Tahun 2015 tanggal 20 April 2015 sebagaimana terlihat dalam tabel berikut:

Tabel 2

Komposisi Kenaikan Angka Kredit Jabatan Widyaisawara Bagi Sub Unsur Pengembangan profesi

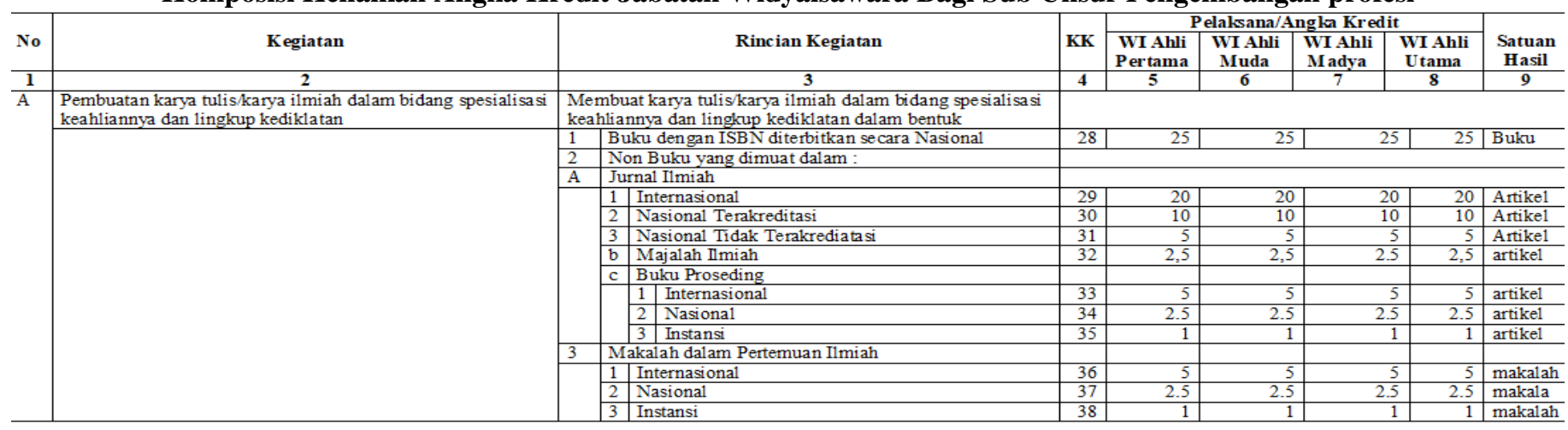


Pada tabel 2 terlihat banyak sekali aktifitas yang berhubungan lansung dengan kompetensi menulis widyaiswara. Masih banyak kegiatan lain yang juga membutuhkan kemampuan menulis, seperti membuat bahan ajar, membuat makalah untuk seminar, membuat laporan, menyusun proposal, dan lain sebagainya. Angka kredit yang diberikan juga cukup besar dibanding kegiatan lainnya. Namun selama ini dirasakan bahwa kemampuan menulis para widyaiswara sangatlah terbatas dan cenderung kurang dapat memenuhi target. Indikasinya antara lain pada waktu pengusulan Daftar Usulan Penghitungan Angka Kredit (DUPAK) yang banyak diantaranya tidak mengusulkan hasil karya tulis. Kemudian juga relatif rendahnya widyaiswara mengirimkan karya tulis ilmiah ke media masa, majalah, bulettin dan jurnal. Apalagi dalam menulis buku, terasa sangat kurang sekali. Padahal kemampuan intelektual menulis buku tersebut sangatlah dibutuhkan, terutama bagi widyaiswara ahli utama dan widyaiswara ahli madya.

\section{Karya Tulis Ilmiah}

Peraturan Kepala Lembaga Administrasi Negara Nomor 9 Tahun 2008 menjelaskan bahwa KTI adalah karya ilmiah dalam bentuk tulisan cetak atau non cetak, yang disusun secara perorangan atau kelompok mengenai penelitian/pengkajian suatu pokok bahasan atau pengembangan gagasan tertentu, dengan cara melakukan identifikasi, deskripsi, analisis, dan memberikan konklusi ataupun rekomendasi. Berdasarkan peraturan tersebut KTI dibagi menjadi tiga yaitu:

1) KTI Populer adalah karya ilmiah yang bertujuan memperkenalkan dan atau menyebarluaskan ilmu pengetahuan dan teknologi yang bersifat kontemporer atau aktual dengan perumusan bahasa yang mudah dipahami oleh masyarakat umum.

2) KTI yang terkait lingkup kediklatan adalah karya ilmiah yang secara substantif berkenaan dengan jenis, isi, dan bidang program diklat, serta sistem diklat, termasuk proses penyelenggaraan dan pembinaan diklat serta aspekaspek lainnya yang berhubungan dengan diklat.

3) KTI yang terkait spesialisasi Widyaiswara adalah karya ilmiah yang secara substantif berkenaan dengan bidang keahlian khusus, yang dimiliki Widyaiswara sesuai dengan latar belakang pendidikan (rumpun keilmuan yang ditekuni) dan/atau pengalaman kerjanya.

Tata Cara Penulisan Berdasarkan Peraturan Kepala LAN No 9 Tahun 2008 Penulisan KTI bagi Widyaiswara pada dasarnya memuat ketentuan atau tata cara penulisan yang berlaku umum dalam penyusunan karya ilmiah. Agar lebih mudah dipahami oleh pembaca, maka penulisan KTI harus memperhatikan tata cara penulisan, sebagai berikut:

1) Kebahasaan

Penggunaan bahasa dengan baik dan benar merupakan salah satu syarat mutlak dalam penulisan KTI agar dapat dipahami dengan mudah oleh para pembacanya. Dari segi penggunaan bahasa dalam penyusunan KTI perlu diperhatikan hal-hal berikut:

a. Dalam bahasa Indonesia: Menggunakan Ejaan Yang Disempurnakan (EYD).

- Untuk kata serapan bahasa asing, dipergunakan cara penulisan kata serapan yang telah dibakukan.

- Penggunaan peristilahan di bidang komputer mengikuti penggunaan istilah sesuai dengan ketentuan yang berlaku.

b. Dalam bahasa Asing: Menggunakan kaidah tata bahasa (gramatikal) dalam bahasa asing yang bersangkutan sesuai dengan ketentuan yang berlaku umum.

2) Abstrak

Abstrak adalah deskripsi singkat tentang isi KTI secara keseluruhan dengan memperhatikan sistematika tulisan yang memuat judul, tujuan dan metode penelitian/kajian, analisis data, temuan penelitian/kajian, kesimpulan dan saran, serta kata kunci (key words). Abstrak ditulis kurang lebih 200-250 kata dan diketik satu spasi.

3) Pengutipan

Pengutipan merupakan cara pengambilan istilah, kata atau kalimat dari sebuah buku, majalah, ataupun ungkapan pernyataan orang lain guna melengkapi dan mendukung atau menolak pendapat atau landasan teori yang dikemukakan oleh penulis di dalam KTI-nya. Dalam merujuk penulis harus mencantumkan sumber informasi yang dikutip agar tidak melanggar hak cipta. Tata cara pengutipan mengikuti aturan-aturan dalam penulisan ilmiah dan dilakukan secara konsisten.

4) Daftar Pustaka

Daftar pustaka berisikan judul buku-buku, artikel-artikel, jurnal, dan sumber bacaan lainnya, sebagai rujukan, acuan yang digunakan dalam penyusunan KTI. Pada dasarnya terdapat lebih dari satu cara atau format dalam penulisan daftar pustaka. Tata cara penulisan daftar pustaka mengikuti aturan-aturan dalam penulis.

\section{Pendidikan dan Pelatihan (Diklat) Karya Tulis Ilmiah Widyaiswara}

Para ahli memiliki pandangan masing-masing terkait dengan Pendidikan. Menurut pasal 1 Peraturan Pemerintah RI Nomor 101 Tahun 2000, dinyatakan bahwa: Pendidikan dan Pelatihan adalah proses penyelenggaraan belajar mengajar dalam rangka meningkatkan kemampuan Pegawai Negeri Sipil. Dengan Pendidikan dan pelatihan 
artinya agar pegawai tersebut memiliki keterampilan dan keahlian serta mampu meningkatkan prestasi kerja yang lebih baik. Karena itu dilakukannya pendidikan dan pelatihan bagi pegawai dengan tujuan untuk merubah sikap dan perilaku pegawai serta memiliki kemampuan, keteram- pilan, kecakapan dan keahlian guna menunjang kegiatan organisasi. Dalam redaksi lain, Hadipoerwono, (1999 : 76) menyatakan bahwa, Pelatihan adalah pembinaan kecakapan, kemahiran, ketangkasan (Skil Building) dalam pelaksanaan tugas. Pelatihan menyangkut proses belajar untuk memperoleh dan meningkatkan keterampilan di luar sistem pendidikan yang berlaku dalam waktu yang relatif singkat dan dengan metode yang lebih mengutamakan praktek daripada teori. Pelatihan adalah proses belajarmengajar, dengan menggunakan tehnik dan metode tertentu. Secara konsepsional dapat dikatakan bahwa pelatihan dimaksudkan untuk meningkatkan keterampilan atau kemampuan kerja seseorang atau sekelompok orang. Biasanya sasarannya adalah seseorang atau sekelompok orang yang sudah bekerja pada suatu organisasi yang efesien, efektivitas dan produktivitas kerjanya dirasakan perlu dan dapat ditingkatkan secara terarah dan pragmatik.

\section{Metode}

Metode library research (peneleitian kepustakaan) dimaksudkan adalah penelitian yang dilaksanakan dengan menggunakan literatur (kepustakaan), baik berupa buku, catatan maupun laporan hasil penelitian dari penelitian terdahulu. Prasetya, dkk (1999) menyebutkan bahwa metode kepustakaan adalah suatu metode yang digunakan untuk mengumpulkan data melalui penelitian kepustakaan guna mencari teori dan informasi-informasi yang berkaitan dengan masalah-masalah yang diteliti. Analisis data merupakan proses menelaah seluruh data yang telah tersedia, yang telah diperoleh melalui pengamatan, wawancara, pencatatan, dokumen dan lain sebagainya (Maleong, 2002: 109).

Dalam redaksi lain dijelaskan bahwa penelitian kepustakaan (library research) adalah penelitian yang dikerjakan untuk memecahkan suatu masalah yang bertumpu pada studi kritis terhadap bahan-bahan pustaka dan hasil penelitian terkait yang disajikan dengan cara baru (Padmo Sukoco, 2002: 209). Di dalam literatur lain (library research), yaitu penelitian yang dilaksanakan dengan menggunakan literatur (kepustakaan), baik barupa buku, catatan, maupun laporan hasil penelitian terdahulu. Kajian pustaka menurut (Mardalis, 2009:28) diartikan sebagai proses umum yang dilakukan peneliti dalam upaya menemukan teori. Secara hakikat data yang diperoleh dengan penelitian perpustakaan ini dapat dijadikan landasan dasar dan alat utama bagi pelaksanaan penelitian lapangan (Hendro Juwono, 2018:110).

Beberapa penjelasan di atas penulis bermaksud bahwa dengan menggunakan penelitian perpustakaan diharapkan dapat memberi informasi dari segala sumber pustaka tentang peningkatan kompetensi widyaiswara dalam meningkatkan kemampuan menulis karya tulis ilmiah melalui diklat karya tulis ilmiah. Teknik keabsahan datanya menggunakan triangulasi sumber dan teknik. Sedangkan Teknik analisis data menggunakan model interaktif dengan proses pengumpulan data, reduksi data, penyajian data dan kesimpulan.

\section{Hasil \\ Problematika Widyaiswara Dalam Menulis Karya Ilmiah}

Setiap pendidik atau tenaga pengajar yang dalam kontesk ini adalah widyasiwara BAPELKES Jambi dalam hal kenaikan pangkat bukan hal mudah tetapi membutuhkan proses yang panjang dalam menyusun DUPAK, mulai dari menyusun RP (Rancangan Pembelajaran) yang tepat, menyusun bahan ajar, menyusun bahan tayang, menyusun bahan atau media pembelajaran yang menarik dan harus sesuai dengan materi yang diajarkan kepada peserta diklat. Proses persiapan ini membutuhkan waktu yang serius dari widyaiswara tersebut.

Gambaran penyusunan DUPAK widyaiswara di atas merupakan hal lazim atau wajib dilakuklan oleh widyaiwara setiap menaiki jabatan yang lebih tinggi lagi, namun setelah itu semua dinilai oleh Lembaga Administrasi Negara (LAN) ternyata kebanyakan widyaiwara terhalang pada bagian unsur pengembangan profesi atau karya tulis ilmiah yang belum memenuhi. Hal ini merupakan suatu permasalahan tersendiri bagi widyaiswara BAPELKES Jambi. Setelah ditelusuri rata-rata permasalah yang dihadapi oleh widyaiswara BAPELKES dalam penulisan karya ilmiah adalah faktor malas dalam menulis, kesibukan dalam mengajar, kurangnya ketrampilan dalam menulis. Selain tugas pokok widyaiswara dalam mendidik, mengajar, melatih, pengembangan dan mengevaluasi, maka yang termasuk penting adalah tugas-tugas menulis dan membuat karya tulis. Hampir semua kegiatan widyaiswara tidak terlepas dari aktifitas menulis, seperti membuat artikel, karya tulis ilmiah, laporan, makalah, buku panduan, buku pedoman, bahan ajar, karya tulis orasi ilmiah dan lain sebagainya. Maka semua widyaiswara harus punya kemampuan menulis agar dapat melaksanakan tugas-tugas pokoknya dengan baik.

Untuk penulisan ini juga telah ada Peraturan Kepala Lembaga Administrasi Negara Nomor 9 Tahun 2008 tentang Penyusunan Karya Tulis Ilmiah bagi Widyaiswara. Dalam peraturan tersebut dinyatakan bahwa salah satu upaya untuk mengembangkan profesionalisme Widyaiswara adalah melalui butir kegiatan penyusunan Karya Tulis Ilmiah (KTI). Pengembangan profesi melalui penyusunan KTI dapat mendorong para Widyaiswara untuk memperkaya wawasan dan memperdalam penguasaan bidang studi yang ditekuni dalam memantapkan spesialisasinya. 
Karya Tulis Ilmiah juga merupakan indikator penguasaan kompetensi profesional Widyaiswara sekaligus media atau sarana komunikasi bagi Widyaiswara dalam menuangkan gagasan dan pengetahuannya dalam rangka mengembangkan bahan ajar dan dan menjamin efektifitas proses pembelajaran.

Ada beberapa macam Karya Tulis Ilmiah (KTI) bagi widyaiswara yang telah diatur dalam Perka-LAN Nomor 9 Tahun 2008 tersebut, yaitu :

1) KTI adalah karya ilmiah dalam bentuk tulisan cetak atau non cetak, yang disusun secara perorangan atau kelompok mengenai penelitian/pengkajian suatu pokok bahasan atau pengembangan gagasan tertentu, dengan cara melakukan identifikasi, deskripsi, analisis, dan memberikan konklusi ataupun rekomendasi,

2) KTI Populer adalah karya ilmiah yang bertujuan memperkenalkan dan atau menyebar luaskan ilmu pengetahuan dan teknologi yang bersifat kontemporer atau aktual dengan perumusan bahasa yang mudah dipahami oleh masyarakat umum,

3) KTI yang terkait lingkup kediklatan adalah karya ilmiah yang secara substantif berkenaan dengan jenis, isi, dan bidang program diklat, serta sistem diklat, termasuk proses penyelenggaraan dan pembinaan diklat serta aspekaspek lainnya yang berhubungan dengan diklat,

4) KTI yang terkait spesialisasi Widyaiswara adalah karya ilmiah yang secara substantif berkenaan dengan bidang keahlian khusus, yang dimiliki Widyaiswara sesuai dengan latar belakang pendidikan (rumpun keilmuan yang ditekuni) dan/atau pengalaman kerjanya,

5) Penelitian atau pengkajian adalah proses kegiatan yang dilakukan secara sistematis mengikuti kaidah, prosedur dan metode ilmiah untuk memperoleh data, dan atau informasi (keterangan) tertentu yang diperlukan dalam penguraian, pembahasan, dan pembuktian asumsi atau pengujian hipotesis, serta menarik kesimpulan bagi kepentingan pengembangan ilmu pengetahuan dan teknologi di bidang tertentu atau penerapannya,

6) Pertemuan ilmiah adalah forum/wadah kegiatan berupa diskusi panel, seminar, lokakarya, konferensi, atau pertemuan sejenisnya yang menyangkut persoalan ilmiah yang diselenggarakan oleh institusi pemerintah atau nonpemerintah. Namun ternyata belum semua widyaiswara dapat memenuhi tuntutan untuk menulis, dan sebagian besar kegiatannya lebih banyak mendidik, mengajar dan melatih (dikjartih), padahal angka kredit dari aktifitas menulis tersebut jauh lebih besar dibandingkan kegiatan lainnya.

\section{Aspek Kemudahan Widyaisawara mengikuti Kegiatan Pelatihan}

Berdasarkan hasil penelitian terkait dengan peluang Widyaiswara mengikuti Pendidikan dan Latihan untuk meningkatkan kompetensi mereka dalam Menyusun karya tulis ilmiahnya dapat dijabarkan bahwa, dalam rangka keseimbangan antara beban kerja dengan widyaiswara maka pihak pimpinan lembaga pada dasarnya memberikan peluang kepada pegawainya untuk mengikuti kegiatan pelatihan seluas-luasnya. Namun mengingat agenda kegiatan ini sifatnya sangat terbatas, maka dalam proses pengiriman peserta ini dilakukan secara adil.

Dalam aspek lainnya, agenda pendidkan dan pelatihan yang dilakukan bertujuan untuk meningkatkan kapasitas dan kompetensi pegawai widyaiswara. Hal ini pihak lembaga telah memberikan kesempatan pada sejumlah pegawai untuk mengikuti pendidikan dan pelatihan serta kegiatan work shop lainnya dan webinar. Mengingat pentingnya bagi kebutuhan widyaiswara, maka dengan mepertimbangkan terbatasnya tenaga widyaiswara di lembaga tersebut, cukup berlasan jika pihak lembaga memberikan kesempatan kepada sejumlah pegawai untuk mengikuti pendidikan pelatihan.

Keputusan ini adalah strategi yang tepat dalam mengantisipasi kesenjangan yang terjadi dilembaga tersebut karena adanya ketidakseimbangan antara beban tugas dengan pegawai widyaiswara yang kompeten. Fakta menunjukkan bahwa pihak kepala Badan telah memberikan kesempatan sebanyak 30 orang untuk mengukuti Pendidikan dan Pelatihan dengan widyaiswara yang tersedia. Sehubungan dengan terbatasnya pegawai widyaiswara, maka pimpinan memberikan kesempatan setiap ada kegiatan pelatihan maka yang kirim adalah 2 orang, selebihnya adalah dari widayaiswara Lembaga lain.

\section{Upaya Meningkatkan Kompetensi Widyasiwara Dalam Menulis Ilmiah (KTI)}

Tabel 3

Tabel Peningkatan Kompetensi Widyaiswara dalam Menulis

\begin{tabular}{c|l|l|l}
\hline \multirow{2}{*}{ No $_{0}$} & \multicolumn{3}{|c}{ Rekomendasi } \\
\cline { 2 - 4 } & \multicolumn{1}{|c}{ Jangka Pendek } & \multicolumn{1}{|c}{ Jangka Menengah } & \multicolumn{1}{|c}{ Jangka Panjang } \\
\hline 1. & $\begin{array}{l}\text { Mengusulkan penginiman widyaiswara untuk mengikuti kegiatan } \\
\text { diklat, seminar, workshop tentang penulisan }\end{array}$ & $\begin{array}{l}\text { Mengusulkan pelaksanakan seminar sehari } \\
\text { bagi widyaiswara }\end{array}$ & $\begin{array}{l}\text { Mengusulkan pelaksanakan Diklat Karya Tulis Ilmiah (KTI) bag } \\
\text { selunh widyaiswara }\end{array}$ \\
\hline 2. & $\begin{array}{l}\text { Mengusulkan untuk mengajak widyaiswara membuat karya tulis } \\
\text { dan menginimkannya ke media masa, }\end{array}$ & $\begin{array}{l}\text { Mengusulkan untuk membuat bengkel karya } \\
\text { tulis guna membahas karya tulis widyaiswara }\end{array}$ & $\begin{array}{l}\text { Mengusulkan untuk membuat penerbitan ilmiah, seperti jurnal yang } \\
\text { diakreditasi oleh LPI }\end{array}$ \\
\hline
\end{tabular}

Sumber: Olahan Data 
Tabel 3 tersebut ada tiga kelompok jangka waktu kegiatan, yaitu :

1) Rekomendasi Kegiatan Jangka Pendek

a. Mengusulkan pengiriman widyaiswara untuk mengikuti kegiatan diklat, seminar, workshop tentang penulisan,

b. Mengusulkan untuk mengajak widyaiswara membuat karya tulis dan mengirimkannya ke media masa,

2) Rekomendasi Kegiatan Jangka Menengah

a. Mengusulkan pelaksanakan seminar atau workshop bagi widyaiswara. Pelaksanaan workshop dilaksanakan selama dua hari dalam bentuk praktek langsung di bawah bimbingan narasumber. Maka semua peserta mempersiapkan diri dengan laptop dan printer disediakan oleh panitia. Disamping praktek lansung menghasilkan sebuah karya tulis ilmiah oleh setiap widyaiswara, maka juga ada pengarahan tentang tata cara menulis di surat kabar dan jurnal ilmiah. Dalam workshop ini setiap widyaiswara ditugaskan untuk membuat sebuah karya tulis ilmiah yang layak dimuat pada jurnal, layak pada surat kabar, layak pada majalah dan sebagainya.

b. Mengusulkan untuk membuat bengkel karya tulis guna membahas karya tulis widyaiswara. Setelah pelaksanaan workshop penulisan karya tulis ilmiah, maka selanjutnya diadakan bengkel penulisan selama dua bulan, yaitu berupa bimbingan dan pembedahan karya tulis oleh nara sumber. Seperti bimbingan membuat skripsi, maka widyaiswara mempunyai pembimbing masing-masing dan disusun jadwal pertemuannya. Setelah dua bulan maka bengkel penulisan dapat diteruskan sesuai kebutuhan dan diharapkan widyaiswara aktif untuk mengikutinya.

3) Rekomendasi Kegiatan Jangka Panjang

a. Mengusulkan pelaksanakan Diklat Karya Tulis Ilmiah (KTI) bagi seluruh widyaiswara

b. Mengusulkan untuk membuat penerbitan ilmiah, seperti jurnal yang diakreditasi oleh Lembaga Ilmu Pengetahuan Indonesia (LIPI).

\section{Pembahasan}

\section{Problematika Widyaiswara Dalam Menulis Karya Ilmiah}

Berdasarkan hasil penelitain terkait dengan beberapa problematika widyaiswara dalam menulis karya ilmiahnya, maka secara aplikatif mereka dihadapkan oleh berbagai persoalan, tidak hanya menyangkut alokasi anggaran dan juga terbatasnya alokasi jumlah peserta yang dipanggil setiap ada kegiatan pelatihan. Walaupun demikian, pendidikan dan pelatihan meskipun secara aplikatif dihadapkan oleh suatu kendala, meski demikian dari upaya yang dilakukan mampu menambah semangat mereka untuk melakukan kegiatan pelatihan lainnya misalnya lewat work shop. Dengan demikian menunjukkan bahwa widyaiswara BAPELKES Jambi, mampu melakukan peningkatan kompetensi menulisnya lewat jalan lain yaitu, mengikuti kegiatan work shop dan belajar lewat tutorial youtube.

\section{Peluang widyaiswara dalam mengikuti Pendidikan dan Pelatihan Karya Tulis Ilmiah}

Berdasarkan hasil analisis data dan penelitian menunjukkan bahwa peluang widyaiswara untuk mengikuti kegiatan Pendidikan dan pelatihan karya tulis ilmiah untuk meningkatkan kompetensinya sangat terbatas, mengingat terbatasnya jumlah atauh kouta pemanggilan dari Lembaga instansinya.

\section{Upaya Meningkatkan Kompetensi Widyasiwara Dalam Menulis Ilmiah (KTI)}

Berdasarkan hasil penelitiannya terkait dengan Upaya meningkatkan Ketrampilan Widyasiwara Dalam Menulis Ilmiah (KTI), maka peneliti dapat menjabarkan sebagai berikut:

a) Rekomendasi Kegiatan Jangka Pendek

b) Mengusulkan pengiriman widyaiswara untuk mengikuti kegiatan diklat, seminar, workshop tentang penulisan,

c) Mengusulkan untuk mengajak widyaiswara membuat karya tulis dan mengirimkannya ke media masa,

d) Rekomendasi Kegiatan Jangka Menengah

e) Mengusulkan pelaksanakan seminar atau workshop bagi widyaiswara. Pelaksanaan workshop dilaksanakan selama dua hari dalam bentuk praktek langsung di bawah bimbingan narasumber. Maka semua peserta mempersiapkan diri dengan laptop dan printer disediakan oleh panitia. Disamping praktek lansung menghasilkan sebuah karya tulis ilmiah oleh setiap widyaiswara, maka juga ada pengarahan tentang tata cara menulis di surat kabar dan jurnal ilmiah. Dalam workshop ini setiap widyaiswara ditugaskan untuk membuat sebuah karya tulis ilmiah yang layak dimuat pada jurnal, layak pada surat kabar, layak pada majalah dan sebagainya.

f) Mengusulkan untuk membuat bengkel karya tulis guna membahas karya tulis widyaiswara. Setelah pelaksanaan workshop penulisan karya tulis ilmiah, maka selanjutnya diadakan bengkel penulisan selama dua bulan, yaitu berupa bimbingan dan pembedahan karya tulis oleh nara sumber. Seperti bimbingan membuat skripsi, maka widyaiswara mempunyai pembimbing masing-masing dan disusun jadwal pertemuannya. Setelah dua bulan maka bengkel penulisan dapat diteruskan sesuai kebutuhan dan diharapkan widyaiswara aktif untuk mengikutinya. 
g) Rekomendasi Kegiatan Jangka Panjang

h) Mengusulkan pelaksanakan Diklat Karya Tulis Ilmiah (KTI) bagi seluruh widyaiswara

i) Mengusulkan untuk membuat penerbitan ilmiah, seperti jurnal yang diakreditasi oleh Lembaga Ilmu Pengetahuan Indonesia (LIPI).

\section{Simpulan}

Profesionalitas Widyaiswara dapat dikembangkan melalui penelitian ilmiah dengan menulis suatu karya tulis ilmiah. Untuk melakukan penulisan karya tulis yang memiliki nilai keilmiahan diperlukan beberapa hal yaitu: Pertama, kaidah Penulisan yang baik perlu memperhatikan aturan Asli, Perlu, Ilmiah, Konsisten dan Objektif. Kedua, berdasarkan Peraturan Kepala LAN No 9 Tahun 2008 Penulisan KTI bagi Widyaiswara pada dasarnya memuat ketentuan atau tata cara penulisan yang berlaku umum dalam penyusunan karya ilmiah sehingga mudah dipahami oleh pembaca. Ketiga, karya tulis ilmiah harus dilakukan uji kelayakan yang meliputi aspek keaslian, kebutuhan, nilai ilmiah, dan konsistensi. Hal ini sebagaimana akronim APIK yaitu Asli, di Perlukan, Ilmiah dalam pembuatannya, dan Konsisten dalam penulisannya serta dilakukan uji keabsahan sebagaimana peraturan perudangundangan yang mengatur tentang KTI Widyaiswara. Keempat, sebagai pelengkap dalam penilaian kualitas suatu karya tulis diperlukan adanya tim penilai dalam melakukan review serta menelaah kelayakan suatu karya tulis ilmiah menjadi benar-benar ilmiah. Kompetensi membuat karya tulis ilmiah ini penting dimiliki oleh seluruh widyaiswara karena semua unsur tugas pokok dapat dilaksanakan atas kemampuan menulis. Maka hampir semua tugas widyaiswara berhubungan tulis-menulis, seperti membuat bahan ajar, membuat artikel, membuat karya tulis ilmiah, membuat proceeding, membuat proposal, membuat laporan ataupun membuat buku. Bahkan karya tulis memiliki point nilai tinggi untuk angka kredit widyaiswara. Namun saat ini kompetensi menulis para widyaiswara diduga masih relatif rendah. Indikasinya adalah tidak banyak widyaiswara yang membuat tulisan yang dapat dimuat pada majalah, surat kabar, buletin, website ataupun buku. Hal ini juga terlihat dari usulan angka kredit oleh widyaiswara yang sangat kurang dari unsur-unsur karya tulis ilmiah meskipun angka kreditnya cukup tinggi. Maka potensi dan kompetensi menulis widyaoswara perlu terus ditingkatkan agar dapat menunjang tugas pokok dan aktualisasi dirinya. Kompetensi menulis karya tulis ilmiah bagi widyaiswara hendaknya dapat terus ditingkatkan melalui berbagai kegiatan, seperti workshop, seminar, Diklat Karya Tulis Ilmiah, diskusi ataupun bimbingan melalui bengkel penulisan karya tulis ilmiah.

\section{Rekomendasi}

Potensi dan kompetensi menulis widyaiswara perlu terus ditingkatkan agar dapat menunjang tugas pokok dan aktualisasi dirinya. Kompetensi menulis karya tulis ilmiah bagi widyaiswara hendaknya dapat terus ditingkatkan melalui berbagai kegiatan, seperti workshop, seminar, Diklat Karya Tulis Ilmiah, diskusi ataupun bimbingan melalui bengkel penulisan karya tulis ilmiah.

\section{Daftar Pustaka}

Ahkyar.2015. Strategi Pengembangan Kompetensi Guru Pendidikan Kewarganegaraan Dalam Penanaman Nilai Karakter Bangsa Di Kabupaten Aceh Besar, Jurnal Serambi Ilmu, Edisi September 2015 Volume 22 Nomor 1. Fakhrurriza dan nurdin. 2019. Pelaksanaan MGMP Dalam Meningkatkan Profesional Guru Pendidikan Agama Islam. Jurnal Serambi Ilmu, Volume 20, Nomor 2, Edisi September 2019.

Hadipoerwono, Tata Personalia. Djembatan. Bandung. 1999.

Hendro Juwono, 2018, Urgensi Penyuluhan Berbasis Wawasan Kebangsaan Terhadap Remaja Masjid, Sekolah Tinggi Islam Blambangan Banyuwangi, h. 110.

Karyana. Pengembangan Profesionalisme Widyaiswara Pasca Permenpan Nomor 14 Tahun 2009, Pusdiklat Bea dan Cukai, 2016

Jamrah A. Pentingnya Workshop dan Pelatihan Meningkatkan Kemampuan Widyaiswara dalam Membuat Karya Tulis Ilmiah.

https://www.sumbarprov.go.id/images/1477626308-

PENTINGNYA\%20WORKSHOP\%20DAN\%20PELATIHAN\%20MENINGKATKAN\%20KEMAMPUAN

\%20WIDYAISWARA.pdf, di akses pada tanggal 25 Agustus 2020

Permana R. 2019. Optimalisasi Profesionalisme Widyaiswara Melalui Peningkatan Kualitas Karya Tulis Ilmiah. Jurnal Teruna Bhakti, Volume 1, No 2, Pebruari 2019; (128-136)

Prasetya, dkk. 1999. Metode Penelitian. Jakarta : Universitas Terbuka

Mardalis, 2009, Metode Penelitian Suatu Pendekatan Proposal, (Jakarta: PT Bumi Aksara.

Maleong, Lexy J. 2002. Metodologi Penelitian Kualitatif. Bandung. Remaja Rosdakarya.

Megawati: 2012. Efektivitas Peningkatan Kemampuan Profesional Guru SMK Di Kabupaten Aceh Besar. Jurnal Pendidikan Serambi Ilmu, Edisi September 2012, Volume 13 Nomor 2, h. 120. 
Padmo Sukoco, 2002. Penelitian Kualitatif: Metodologi, Aplikasi, dan Evaluasi, Jakarta: Gunung Agung.

Perarturan Kepala LAN No 9 Tahun 2008. Pedoman Penyusunn Karya Tulis Ilmiah bagi Widyaiswara, Peraturan Kepala Lembaga Administrasi Negara. Jakarta.

Perarturan Kepala LAN No. 26 Tahun 2015. Pedoman Penilaian Angka Kredit Jabatan Fungsional Widyaiswara. Jakarta.

Zainuddin. 2014. Meningkatkan Keterampilan Guru Kelas Membuat Perangkat Pembelajaran Berbasis Kurikulum Tingkat Satuan Pendidikan. Jurnal Serambi Ilmu, Edisi September 2014 Volume 19 Nomor 2, h. 105 